$\begin{array}{llll}\text { JURNAL SEHAT MASADA VOLUME XIV NOMOR } 2 & \text { Juli } 2020 & \text { p-ISSN : 1979-2344 } \\ & \text { e-ISSN : 2502-5414 }\end{array}$

\title{
HUBUNGAN TINGKAT KEPUASAN IBU HAMIL DENGAN PEMERIKSAAN KEHAMILAN DI PUSKESMAS JATINANGOR
}

\author{
Fardila Elba $^{1}$, Gita Noor Syifa ${ }^{2}$ \\ 1, Departemen Ilmu Kesehatan Masyarakat, Fakultas Kedokteran, Universitas Padjadjaran \\ fardilaelba@yahoo.com \\ ${ }^{2}$ Program Studi Diploma Kebidanan, Fakultas Kedokteran,Universitas Padjadjaran \\ Gitanoorsyifa01@gmail.com
}

\begin{abstract}
ABSTRAK
Kemkes-WHO-HOGSI 2012, data kualitas ANC di Puskesmas mengenai pemeriksaan fisik umum dan obstetrik 59,38\%, melakukan konseling sekitar $45 \%$, melakukan pemeriksaan penunjang rutin 19,69\%, melakukan pemeriksaan penunjang bila ada indikasi 52,50\% dan memberikan suplemen dan imunisasi $73,13 \%$. Hal ini menyangkut kepuasan pasien sehingga menjadi bagian penting dan diperlukan untuk mengukur mutu suatu pelayanan. Informasi kesehatan saat ini dengan mudah didapatkan, semakin banyak masyarakat yang mengetahui tentang kesehatan maka semakin banyak tuntutan yang diinginkan oleh masyarakat.

Tujuan penelitian ini adalah untuk mengetahui bagaimana hubungan tingkat kepuasan ibu hamil tentang pemeriksaan kehamilan di Puskesmas Jatinangor.

Jenis penelitian ini adalah kuantitatif. Analisis yang digunakan univariat dan bivariat dengan jumlah sampel sebanyak 101 orang ibu hamil di Puskesmas Jatinangor 2016. Pengambilan sampel dengan accidental sampling. Pada penelitian ini digunakan kuesioner sebagai cara untuk pengumpulan data penelitian dan menggunakan analisis non-parametrik dengan korelasi rank spearman.

Hasil penelitian ini didapatkan responden cenderung puas terhadap pemeriksaan kehamilan sebanyak 50.5\%. Setelah diuji dengan statistik analisis bivariat terdapat hubungan tingkat kepuasan ibu hamil dengan pemeriksaan kehamilan di Puskesmas Jatinangor. Karena pada peneitian ini terdapat hubungan signifikan antara nilai skor total dari lima dimensi dengan kepuasan karena nilai sig $<0.05$ dan corelation coefficient bernilai 0.867 .

Simpulan pada penelitian ini yaitu pemeriksaan kehamilan yang berkualitas berhubungan dengan kepuasan ibu hamil. Ini artinya secara keseluruhan kepuasan ibu hamil memiliki hubungan dengan pemeriksaan kehamilan berdasarkan dimensi kenyataan/ wujudannya (tangible), dimensi kehandalan (realibility), dimensi daya tangkap (responsiveness), dimensi jaminan (assurance) dan dimensi perhatian (empathy).
\end{abstract}

Kata kunci: Ibu hamil, pemeriksaan kehamilan, tingkat kepuasan

\section{CORRELATION BETWEEN SATISFACTION OF PREGNANT WOMEN WITH PREGNANCY EXAMINATION AT PUSKESMAS JATINANGOR}

\section{ABSTRACT}

Kemkes-WHO-HOGSI 2012, ANC quality data at Puskesmas on general physical and obstetric examination $59,38 \%$, counseling $45 \%$, performing routine investigation 19,69\%, conducting investigation if there is indication 52,50\% and giving Supplements and immunization $73.13 \%$. This concerns patient satisfaction so that it becomes an important and necessary part to measure the quality of a service. The current health information is easily obtained, the more people who know about health the more demands the community wants. 
The purpose of this study was to find out how the relationship of maternal satisfaction level about pregnancy examination in Puskesmas Jatinangor.

This type of research is quantitative. The analysis used univariate and bivariate with number of samples counted 101 pregnant women at Puskesmas Jatinangor 2016. Sampling with accidental sampling. In this study used questionnaires as a way to collect research data and use non-parametric analysis with rank spearman correlation.

The results of this study obtained respondents tend to be satisfied with the examination of pregnancy as much as 50.5\%. After tested with bivariate analysis statistics, there is a relation between maternal satisfaction level and pregnancy examination at Puskesmas Jatinangor. Because in this study there is a significant relationship between the total score score of five dimensions with satisfaction because the value of sig $<0.05$ and corelation coefficient is worth 0.867 .

Conclusions in this study is a quality pregnancy examination associated with maternity satisfaction. This means that the overall satisfaction of pregnant women has a relationship with the examination of pregnancy based on the dimension of reality (tangible), dimensions of reliability (realibility), dimensions of capability (responsiveness), the dimension of assurance (assurance) and attention dimension (empathy).

Keywords: Pregnant mother, pregnancy examination, level of satisfaction

\section{PENDAHULUAN}

Berdasarkan Survei Demografi dan Kesehatan Indonesia (SDKI) tahun 2012, angka kematian ibu di Indonesia masih tinggi sebesar 359 per 100.000 kelahiran hidup Angka ini sedikit meningkat jika dibandingkan dengan SDKI tahun 2007, yaitu sebesar 228 per 100.000 kelahiran hidup. ${ }^{1}$ Berdasarkan Profil Kesehatan Kabupaten/Kota di Provinsi Jawa Barat Tahun 2012 jumlah kematian ibu maternal yang terlapor sebanyak 804 orang (86,3/100.000 kelahiran hidup), tertinggi terdapat di Kabupaten Sukabumi dan Cirebon, dan teredah di Kota Cirebon dan Kota Bandung. Di Kabupaten Sumedang tercatat angka kematian ibu sebanyak 14/100.000 $\mathrm{KH}^{2}$

Capaian pelayanan kesehatan ibu hamil dapat dinilai dengan menggunakan indikator Cakupan K1 dan K4. Indikator tersebut memperlihatkan akses pelayanan kesehatan terhadap ibu hamil dan tingkat kepatuhan ibu hamil dalam memeriksakan kehamilannya ke tenaga kesehatan. ${ }^{1}$

Secara umum cakupan pelayanan kesehatan ibu hamil K1 dan K4 mengalami kenaikan tersebut menunjukan semakin baiknya akses masyarakat terhadap pelayanan kesehatan ibu hamil yang diberikan oleh tenaga kesehatan. Kenaikan cakupan K1 dari tahun ke tahun relatif lebih stabil jika dibandingkan dengan cakupan K4. Cakupan K1 selalu mengalami peningkatan, kecuali di tahun 2013 dimana angkanya mengalami penurunan dari 96,84\% pada tahun 2012 menjadi 95,25\% pada tahun 2013. Cakupan kunjungan ibu hamil di Provinsi jawa barat K1 100,1\% dan K4 90,7\%. Di Kabupaten Sumedang cakupan K1 sebanyak $98,4 \%$ dan K4 $87,1 \%{ }^{1}$

Hasil Assesment kualitas pelayanan kesehatan maternal oleh Kemkes-WHO- 
JURNAL SEHAT MASADA VOLUME XIV

HOGSI 2012, data kualitas ANC di Puskesmas mengenai pemeriksaan fisik umum dan obstetrik 59,38\%, melakukan konseling sekitar $45 \%$, melakukan pemeriksaan penunjang rutin 19,69\%, melakukan pemeriksaan penunjang bila ada indikasi $52,50 \%$ dan memberikan suplemen dan imunisasi 73,13\%. Dalam hal ini menunjukan bahwa peran tenaga kesehatan untuk memberikan informasi dan advokasi kepada ibu dan keluarga pada saat ANC masih lemah sehingga pengetahuan keluarga dan masyarakat untuk melakukan pemeriksaan kehamilan dan membuat perencanaan persalinan juga rendah. ${ }^{3}$

Evaluasi kepuasan pasien menjadi bagian penting dan diperlukan untuk mengukur mutu suatu pelayanan. Pengalaman membuktikan bahwa transformasi ekonomi akan mengubah keinginan dan kebutuhan masyarakat terhadap layanan kesehatan, termasuk layanan pemeriksaan. Informasi kesehatan saat ini dengan mudah didapatkan, semakin banyak masyarakat yang mengetahui tentang kesehatan maka semakin banyak tuntutan yang diinginkan oleh masyarakat. Bila sebagai tenaga kesehatan tidak dapat memenuhi kebutuhan masyarakat tentunya akan menjadi masalah. Melalui masukan yang diberikan oleh pasien dapat meningkatkan mutu pelayanan kesehatan.

Berdasarkan uraian latar belakang di atas, penulis merasa tertarik untuk melakukan penelitian dengan judul "Hubungan Tingkat Kepuasan Ibu Hamil dengan Pemeriksaan Kehamilan di Puskesmas Jatinangor".
NOMOR 2 Juli 2020

p-ISSN : 1979-2344

e-ISSN : 2502-5414

\section{METODE}

Jenis penelitian yang digunakan adalah secara kuantitatif. Analisis yang digunakan univariat dan bivariat. Penelitian ini bertujuan untuk mengetahui gambaran dan menghubungkan tingkat kepuasan ibu hamil dengan pemeriksaan kehamilan di Puskesmas Jatinangor pada Tahun 2016. populasi berjumlah $362 \mathrm{ibu}$ hamil. Teknik pengambilan sempel menggunakan accidental sampling yaitu pengambilan sampel ibu hamil trimester I, trimester II, dan trimester III. Sampel yang digunakan sebanyak $101 \mathrm{ibu}$ hamil. Instrumen pada penelitian ini menggunakan kuesioner atau dimana teknik pengumpulan data dalam bentuk wawancara terpimpin dengan menggunakan skala Likert. Pengolahan data menggunakan kategorisasi dengan nilai mean atau median dibantu dengan program SPSS. Penelitian ini menggunakan analisis nonparametrik korelasi rank spearman dengan menguhubungkan skor total kepuasan dengan pemeriksaan kehamilan.

\section{HASIL}

Penelitian dilakukan kepada ibu hamil trimester I, trimester II, dan trimester III yang melakukan pemeriksaan kehamilan di Puskesmas Jatinangor. Sampel yang digunakan sebanyak 101 ibu hamil. Penelitian ini telah disetujui oleh Komite Etik Penelitian Kesehatan Fakultas Kedokteran Universitas Padjadjaran No. 791 /UN6.C1.3.2/KEPK/PN/2016. 
Tabel 1 Distribusi frekuensi karakteristik ibu hamil di Puskesmas Jatinangor Tahun 2016

\begin{tabular}{lcc}
\hline \multicolumn{1}{c}{ Karakteristik } & f & \% \\
\hline 1. Usia & & \\
\hline$<20$ tahun & 5 & 5.0 \\
\hline $20 \quad 35$ tahun & 79 & 78.2 \\
\hline$>35$ tahun & 17 & 16.8 \\
\hline Total & $\mathbf{1 0 1}$ & $\mathbf{1 0 0}$ \\
\hline$\quad$ & \\
\hline 2. Paritas & & 29.7 \\
\hline Primigravida & 30 & 68.3 \\
\hline Multigravida & 69 & 2.0 \\
\hline Grande multigravida & 2 & $\mathbf{1 0 0}$ \\
\hline Total & $\mathbf{1 0 1}$ & \\
\hline
\end{tabular}

\section{Pendidikan}

\begin{tabular}{lcc}
\hline SD & 20 & 19.8 \\
\hline SMP & 37 & 36.6 \\
\hline SMA & 41 & 40 \\
\hline Perguruan Tinggi & 3 & 3.0 \\
\hline Total & $\mathbf{1 0 1}$ & $\mathbf{1 0 0}$ \\
\hline
\end{tabular}

\section{Pekerjaan}

Tidak bekerja

Bekerja

Total

\begin{tabular}{cc|}
\hline 69 & 68.3 \\
\hline 32 & 31.7 \\
\hline $\mathbf{1 0 1}$ & $\mathbf{1 0 0}$ \\
\hline
\end{tabular}

Berdasarkan tabel 1 diketahui responden yang berusia 20-35 tahun sebanyak $78.2 \%$, multigravida sebanyak $68.3 \%$, berpendidikan SMA sebanyak 40.6\%. tidak bekerja sebanyak $68.3 \%$.

\section{Tabel 2 Distribusi frekuensi tingkat kepuasan ibu hamil di Puskesmas Jatinangor Tahun 2016}

\begin{tabular}{lcc}
\hline Tingkat Kepuasan & f & \% \\
\hline Puas & 51 & 50.5 \\
\hline Tidak Puas & 50 & 49.5 \\
\hline Total & 101 & 100 \\
\hline
\end{tabular}

Berdasarkan hasil distribusi frekuensi tingkat kepuasan ibu hamil di Puskesmas
Jatinangor diketahui responden cenderung puas sebanyak $50.5 \%$.

Tabel 3 Distribusi Frekuensi tingkat kepuasan ibu hamil terhadap dimensi

\begin{tabular}{lcccc}
\hline \multirow{2}{*}{ Dimensi } & \multicolumn{2}{c}{ Puas } & \multicolumn{2}{c}{ Tidak Puas } \\
\cline { 2 - 5 } & f & \% & f & \% \\
\hline Tangible & 60 & 59.4 & 41 & 40.6 \\
\hline Realibility & 56 & 55.4 & 45 & 44.6 \\
\hline Responsiveness & 73 & 72.3 & 28 & 27.7 \\
\hline Assurance & 72 & 71.3 & 29 & 28.7 \\
\hline Empathy & 91 & 90.1 & 10 & 9.9 \\
\hline
\end{tabular}

Berdasarkan hasil data distribusi frekuensi tingkat kepuasan ibu hamil pada dimensi kenyataan/ wujudannya (tangible) responden merasa puas sebanyak 59.4\%. Pada dimensi kehandalan (realibility) puas sebanyak 55.4\%. Pada dimensi daya tangkap (responsiveness) puas sebanyak $72.3 \%$. Pada dimensi jaminan (assurance) puas sebanyak 71.3\%. Pada dimensi perhatian (empathy) puas sebanyak $90.1 \%$.

\section{Tabel 4 Hubungan Kepuasan Ibu Hamil dengan Pemeriksaan Kehamilan}

\begin{tabular}{lccc}
\hline \multirow{2}{*}{ Dimensi } & \multicolumn{2}{c}{ Skor Total Kepuasan } \\
\cline { 2 - 4 } & $\begin{array}{c}\text { Correlation } \\
\text { Coefficient }\end{array}$ & $\begin{array}{c}\text { Sig. (2- } \\
\text { tailed) }\end{array}$ & $\mathrm{N}$ \\
\hline Tangible & 0.865 & 0.000 & 101 \\
\hline Realibility & 0.883 & 0.000 & 101 \\
\hline Responsiveness & 0.790 & 0.000 & 101 \\
\hline Assurance & 0.799 & 0.000 & 101 \\
\hline Empathy & 0.539 & 0.000 & 101 \\
\hline Total & 0.867 & 0.000 & 101 \\
\hline
\end{tabular}


JURNAL SEHAT MASADA VOLUME XIV

Berdasarkan tabel Intepretasi pemeriksaan kehamilan berdasarkan dimensi dengan skor kepuasan memiliki pengaruh yang bermakna.

\section{PEMBAHASAN}

Berdasarkan karakteristik usia ibu hamil yang melakukan pemeriksaan kehamilan di Puskesmas Jatinangor hampir seluruhnya berumur 20-35 tahun sejumlah 79 ibu hamil $(78,2 \%)$ merasa puas dengan pelayanan pemeriksaan kehamilan. Pada hasil penelitian ini umur dapat mempengaruh pola pikir manusia, semakin cukup umur maka tingkat kematangan dan pengalaman seseorang akan lebih matang dalam berfikir, dengan adanya kemajuan ilmu pengetahuan dan teknologi maka pola pikir manusia semakin maju dan semakin kritis. Semakin bertambah umur, ibu hamil akan memiliki pengetahuan yang baik tentang kepuasan. ${ }^{10}$

Berdasarkan karakteristik pekerjaan ibu hamil yang melakukan pemeriksaan kehamilan di Puskesmas Jatinangor hampir seluruhnya tidak bekerja sejumlah 69 ibu hamil (68.3\%\%). Berdasarkan hasil penelitian pekerjaan ibu hamil, ibu hamil yang mempunyai pekerjaan akan memiliki pengetahuan tentang kepuasan dengan baik. Sebaliknya, ibu hamil yang tidak bekerja akan memiliki pengetahuan kepuasan dengan cukup dan kurang. Status pekerjaan memberikan kontribusi terhadap pengetahuan ibu hamil. Status ibu rumah tangga adalah pekerjaan mengurus rumah tangga yang sebagian besar waktunya banyak di dalam rumah, apabila tidak diikuti oleh kegiatan
NOMOR 2 Juli 2020

p-ISSN : 1979-2344

e-ISSN : 2502-5414

sosial seperti ikut kegiatan kemasyarakatn untuk saling bertukar informasi yang diterima terbatas. Selain itu, pekerjaan secara langsung akan mempengaruhi status ekonomi seseorang. Seseorang yang berpenghasilan di atas ratarata mempunyai minat yang lebih tinggi dalam memilih pelayanan kesehatan. ${ }^{10}$

Berdasarkan karakteristik pendidikan ibu hamil yang melakukan pemeriksaan kehamilan di Puskesmas Jatinangor kurang dari setengahnya ibu hamil berpendidikan SMA sebanyak 41 ibu hamil (40,6\%). Berdasarkan hasil penelitian hubungannya dengan tingkat pendidikan, tingkat pendidikan ibu hamil yang mempunyai pendidikan tinggi akan memiliki pengetahuan tentang kepuasan dengan baik, sedangkan tingkat pendidikan rendah akan memiliki pengetahuan kepuasan dengan kurang baik. Oleh karena itu, pendidikan ibu hamil merupakan salah satu faktor penting dalam meningkatkan pengetauhan karena dengan pendidikan yang baik maka ibu hamil dengan mudah memiliki pengetahuan kepuasan dengan baik. ${ }^{10}$

Kepuasan ibu hamil tentang pemeriksaan kehamilan di Puskesmas Jatinangor Tahun 2016 setengahnya ibu hamil mengatakan puas berjumlah 51 ibu hamil (50.5\%) dan tidak puas berjumlah $50 \quad(49.5 \%)$. Tingkat kepuasan pelayanan ibu hamil timbul dari persepsi ibu hami terhadap pelayanan pemeriksaan kehamilan yang diberikan akan tercapai bila diperoleh hasil yang optimal pada setiap pemeriksaan. Pelayanan kesehatan memperhatikan kemampuan ibu dan 
JURNAL SEHAT MASADA VOLUME XIV

keluarganya, ada perhatian terhadap keluhan, kondisi lingkungan fisik dan tanggap kepada kebutuhan ibu hamil sehingga tercapai keseimbangan yang sebaik-baiknya antara rasa tingkat puas dan jerih payah yang harus dialami guna memperoleh hasil tersebut. ${ }^{13}$

Adanya kelengkapan peralatan, sarana dan prasarana, ruang tunggu dan lingkungan yang bersih, nyaman dan teratur, sikap bidan yang ramah pada saat melakukan pelayanan, dan empati terhadap keluhan ibu hamil akan mempengaruhi kepuasan ibu hamil terhadap pemeriksaan kehamilan. ${ }^{6}$

Tingkat kepuasan ibu hamil tentang pemeriksaan kehamilan di Puskesmas Jatinangor Tahun 2016 Pada Dimensi Kenyataan/ wujudanya (Tangibel) setengahnya ibu hamil sudah merasa puas berjumlah $60 \mathrm{ibu}$ hamil (59.4\%) dan tidak puas berjumlah $41 \mathrm{ibu}$ hamil $(40.6 \%)$.

Kenyataan/ wujudannya (Tangibles) yaitu meliputi fasilitas fisik, peralatan, pegawai, dan media komunikasi yang dapat dirasakan langsung oleh pelanggan yaitu bidan menyambut ibu dengan ramah dan sopan, begitu ibu sampai di tempat pelayanan, bidan mengucapkan salam, bidan selalu mempersiapkan alat sebelum melakukan pemeriksaan kehamilan ibu, bidan menjaga ruangan agar bersih dan nyaman, dan sebelum melakukan pemeriksaan bidan mencuci tangan terlebih dahulu. ${ }^{3}$

Selain itu pada penelitian ini faktor yang mempengaruhi tingkat kepuasan pada dimensi Kenyataan/ wujudanya (Tangibel) yaitu umur
NOMOR 2 Juli 2020

p-ISSN : 1979-2344

e-ISSN : 2502-5414

karena kebutuhan seseorang terhadap suatu barang atau jasa akan semakin meningkat seiring bertambahnya usia. Faktanya kebutuhan terhadap pelayanan kuratif atau pengobatan semakin meningkat saat usia mulai meningkat dibandingkan dengan kebutuhan terhadap pelayanan preventif. ${ }^{10}$

Tingkat kepuasan ibu hamil tentang pemeriksaan kehamilan di Puskesmas Jatinangor Tahun 2016 Pada Dimensi kehandalan (Reliability) setengahnya ibu hamil sudah merasa puas berjumlah 56 ibu hamil (55.4\%) dan tidak puas berjumlah 45 ibu hamil $(44.6 \%)$.

Kehandalan (Reabillithy) yaitu kemampuan untuk memberikan pelayanan yang tepat dan terpercaya. Pelayanan yang terpercaya artinya adalah konsisten. Sehingga reliability mempunyai dua aspek penting yaitu kemampuan memberikan pelayanan seperti yang dijanjikan dan seberapa jauh mampu memberikan pelayanan yang tepat sesuai standar pemeriksaan kehamilan yaitu bidan memberitahu ibu tujuan pemeriksaan kehamilan dilakukan, bidan menjelaskan taksiran usia kehamilan ibu sesuai dengan hasil pemeriksaan, bidan menimbang berat badan dan memeriksa tekanan darah serta memberitahukan pada ibu hasil pemeriksaannya, bidan memberikan suntik tetanus toxoid (TT) dan bidan selalu memberikan tablet Zat besi (Fe) dan menyanjurkan ibu untuk meminumnya secara teratur. ${ }^{3,6}$ 
JURNAL SEHAT MASADA VOLUME XIV

Selain itu responden yang merasa tidak puas paling tinggi dengan pelayanan yang diberikan terdapat pada dimensi kehandalan (Reabillithy) sebanyak 44.6\%. Kemungkinan ketidakpuasan itu muncul karena bidan tidak memberitahu ibu tujuan pemeriksaan kehamilan dilakukan, bidan tidak menjelaskan taksiran usia kehamilan ibu dengan jelas sesuai hasil pemeriksaan, bidan tidak menimbang berat badan dan memeriksa tekanan darah serta tidak memberitahukan pada ibu hasil pemeriksaannya, bidan tidak memberikan suntik tetanus toxoid (TT) dan bidan tidak memberikan tablet Zat besi $(\mathrm{Fe})$ dan tidak menyanjurkan ibu untuk meminumnya secara teratur.

Pada standar pelayanan pemeriksaan kehamilan tenaga kesehatan harus dapat memastikan bahwa kehamilan berlangsung normal, maupun mendeteksi dini masalah dan penyakit yang dialami ibu hamil, melakukan intervensi secara adekuat sehingga ibu hamil siap untuk menjalani persalinan normal. ${ }^{3}$

Setiap kehamilan, dalam perkembangannya mempunyai risiko mengalami penyulit atau komplikasi. Oleh karena itu, pelayanan antenatal harus dilakukan secara rutin, sesuai standar dan terpadu untuk antenatal yang berkualitas. ${ }^{3}$

Tingkat kepuasan ibu hamil tentang pemeriksaan kehamilan di Puskesmas Jatinangor Tahun 2016 Pada Dimensi daya tangkap (Responsiveness) lebih dari setengahnya ibu hamil cenderung merasa puas
NOMOR 2 Juli 2020

p-ISSN : 1979-2344

e-ISSN : 2502-5414

berjumlah $73 \mathrm{ibu}$ hamil (72.3\%) dan tidak puas 28 ibu hamil (27.7\%).

Daya tangkap (Responsiveness) yaitu kesediaan atau kemauan untuk membantu pelanggan dan memberikan pelayanan yang cepat seperti: Bidan cepat tanggap dengan keluhan yang ibu rasakan selama kehamilan, bidan memberikan nasehat dan pemecahan masalah keluhan yang ibu rasakan sesuai keluhan, bidan memberitahukan langsung ibu hasil temuan dari pemeriksaan kehamilan yang dilakukan, ketika melakukan pemeriksaan kehamilan bidan membantu ibu berbaring di tempat tidur, dan bidan dalam memberikan pelayanan memberitahu kepada ibu proses pemeriksaan apa saja yang dilakukan selama kehamilan. ${ }^{3,6}$

Pada standar pelayanan pemeriksaan kehamilan tenaga kesehatan harus dapat memastikan bahwa kehamilan berlangsung normal, maupun mendeteksi dini masalah dan penyakit yang dialami ibu hamil, melakukan intervensi secara adekuat sehingga ibu hamil siap untuk menjalani persalinan normal. ${ }^{3}$

Setiap kehamilan, dalam perkembangannya mempunyai risiko mengalami penyulit atau komplikasi. Oleh karena itu, pelayanan antenatal harus dilakukan secara rutin, sesuai standar dan terpadu untuk antenatal yang berkualitas. $^{3}$

Tingkat kepuasan ibu hamil tentang pemeriksaan kehamilan di Puskesmas Jatinangor Tahun 2016 Pada Dimensi jaminan (Assurance) hampir seluruhnya ibu hamil sudah merasa puas berjumlah 72 ibu hamil 
JURNAL SEHAT MASADA VOLUME XIV

(71.3\%) dan tidak puas berjumlah 29 ibu hamil $(28.7 \%)$.

Jaminan (Assurance) yaitu mencakup pengetahuan, kompetensi, kesopanan, dan sifat dapat dipercaya yang dimiliki staf (bebas dari bahaya, risiko atau keragu-raguan) karena setiap ibu hamil memeiliki hak-hak ketika menerima layanan asuhan pada kehamilan seperti: bidan memberitahu ibu setiap manfaat pemeriksaan kehamilan yang dilakukan, bidan memberitahu dengan jelas tentang perawatan yang harus dilakukan ibu selama kehamilan seperti perawatan payudara, bidan memberikan penjelasan setiap pemeriksaan kehamilan yang dilakukan, bidan menjelaskan serta mengarahkan tempat persalinan yang aman, dan pelayanan yang diberikan bidan membuat keluhan ibu berkurang. ${ }^{3}$

Karena pasien akan merasa puas apabila kinerja layanan kesehatan yang diperolehnya sama atau melebihi harapannya dan sebaliknya, ketidakpuasan atau perasaan kecewa pasien akan muncul apabila kinerja layanan kesehatan yang diperoleh itu tidak sesuai dengan harapannya.

Tingkat kepuasan ibu hamil tentang pemeriksaan kehamilan di Puskesmas Jatinangor Tahun 2016 Pada Dimensi empati (Empathy) hampir seluruh ibu hamil cendurung merasa puas berjumlah 91 ibu hamil (90.1\%) dan tidak puas berjumlah $10 \mathrm{ibu}$ hamil $(9.9 \%)$.

Empati (Empathy) membina hubungan yang baik, pemahaman atas kebutuhan individual para pelanggan, dan memberikan pelayanan
NOMOR 2 Juli 2020

p-ISSN : 1979-2344

e-ISSN : 2502-5414

serta perhatian secara individual pada pelanggannya, seperti: bidan selalu mendengarkan setiap keluhan ibu dengan baik dan membantu menyelesaikannya, bidan memberikan kesempatan kepada ibu untuk bertanya tentang kehamilannya, bidan selalu mendiskusikan tentang kemungkinan yang terjadi selama kehamilan ibu, bidan selalu memberikan perhatian yang baik dan menghargai setiap pertanyaan ibu tentang kehamilan dan pemeriksaaan yang dilakukan, dan bidan membantu ibu dalam mempersiapkan persalinan dan menghargai pendapat ibu tentang tempat persalinan. ${ }^{3,6,9}$

Berdasarkan tabel 1 Intepretasi pemeriksaan kehamilan dimensi tangible dengan kepuasan memiliki nilai signifikan < 0.05 sehingga pada pemeriksaan kehamilan dengan dimensi ini memiliki hubungan signifikan antara nilai tangible dengan kepuasan dan memiliki nilai correlation coefficient 0.865 sehingga dapat disimpulkan pada dimensi ini memiliki hubungan sangat tinggi antara tangible dan skor kepuasan.

Berdasarkan tabel 2 Intepretasi pemeriksaan kehamilan dimensi reliability dengan kepuasan memiliki nilai signifikan < 0.05 sehingga pada pemeriksaan kehamilan dengan dimensi ini memiliki hubungan signifikan antara nilai tangible dengan kepuasan dan memiliki nilai correlation coefficient 0.883 sehingga dapat disimpulkan pada dimensi ini memiliki hubungan sangat tinggi antara reliability dan skor kepuasan. 
JURNAL SEHAT MASADA VOLUME XIV

Berdasarkan tabel 3 Intepretasi pemeriksaan kehamilan dimensi responsive dengan kepuasan memiliki nilai signifikan < 0.05 sehingga pada pemeriksaan kehamilan dengan dimensi ini memiliki hubungan signifikan antara nilai tangible dengan kepuasan dan memiliki nilai correlation coefficient 0.790 sehingga dapat disimpulkan pada dimensi ini memiliki hubungan sangat tinggi antara responsive dan skor kepuasan.

Berdasarkan tabel 4 Intepretasi pemeriksaan kehamilan dimensi assurance dengan kepuasan memiliki nilai signifikan < 0.05 sehingga pada pemeriksaan kehamilan dengan dimensi ini memiliki hubungan signifikan antara nilai tangible dengan kepuasan dan memiliki nilai correlation coefficient 0.799 sehingga dapat disimpulkan pada dimensi ini memiliki hubungan sangat tinggi antara assurance dan skor kepuasan.

Berdasarkan tabel 5 Intepretasi pemeriksaan kehamilan dimensi empathy dengan kepuasan memiliki nilai signifikan < 0.05 sehingga pada pemeriksaan kehamilan dengan dimensi ini memiliki hubungan signifikan antara nilai tangible dengan kepuasan dan memiliki nilai correlation coefficient 0.539 sehingga dapat disimpulkan pada dimensi ini memiliki hubungan sedang antara empathy dan skor kepuasan.

Sebagai profesional bidan, dalam melaksanakan praktiknya harus sesuai dengan standar pelayanan kebidanan yang berlaku. Standar mencerminkan norma, pengetahuan dan tingkat kinerja yang telah disepakati oleh
NOMOR 2 Juli 2020

p-ISSN : 1979-2344

e-ISSN : 2502-5414

profesi. Penerapan standar pelayanan akan sekaligus melindungi masyarakat karena penilaian terhadap proses dan hasil pelayanan. ${ }^{3}$

Kepuasan pasien menjadi bagian penting dan diperlukan untuk mengukur mutu suatu pelayanan. Pengalaman membuktikan bahwa transformasi ekonomi akan mengubah keinginan dan kebutuhan masyarakat terhadap layanan kesehatan, termasuk layanan pemeriksaan. Informasi kesehatan saat ini dengan mudah didapatkan, semakin banyak masyarakat yang mengetahui tentang kesehatan maka semakin banyak tuntutan yang diinginkan oleh masyarakat. Bila sebagai tenaga kesehatan tidak dapat memenuhi kebutuhan masyarakat tentunya akan menjadi masalah. Melalui masukan yang diberikan oleh pasien dapat meningkatkan mutu pelayanan kesehatan.

Sehingga dapat disimpulkan bahwa pemeriksaan yang berkualitas berhubungan dengan kepuasan pasien. Karena pada peneitian ini terdapat hubungan signifikan antara nilai skor total kepuasan dengan pemeriksaan kehamilan berdasarkan dimensi kenyataan/ wujudannya tangible), dimensi kehandalan (realibility), dimensi daya tangkap (responsiveness), dimensi jaminan (assurance) dan dimensi perhatian (empathy) karena nilai sig $<0.05$ dan corelation coefficient bernilai 0.867 .

\section{DAFTAR PUSTAKA}

1. Kemenkes RI. INFODATIN. Pusat Data dan Informasi. KEMENKES RI. 2014. 
2. Dinas Kesehatan Provinsi Jawa Barat. Profil Kesehatan Jawa Barat tahun 2012. Departemen Kesehatan. 2008.

3. Kemenkes. Pedoman Pelayanan Antenatal Terpadu. Jakarta : Bina Kesehatan Masyarakat. 2010.

4. Pohan, Imbalo S. Jaminan Mutu Layanan Kesehatan. Jakarta : EGC. 2006; 143; $156 ; 157$.

5. Notoatmodjo, S. Metodelogi Penelitian Kesehatan. Jakarta : Rineka. 2010.

6. J. Supranto. Statiska Teori dan Aplikasi Jilid I Edisi 7. Jakarta : Erlangga. 2009; 21.

7. Direktorat Keperawatan dan Keteknisian Medik Direktorat Jendral Pelayanan Medik Departemen Kesehatan RI. Dasardasar Asuhan Kebidanan. Jakarta. 2003; 14.

8. Abd Nasir, Abdul Muhith, M. E. Ideputri. Buku Ajar Metodelogi Penelitian Kesehatan: Pembuatan Karya Tulis dan Thesis untuk Mahasiswa Kesehatan. Yogyakarta : Nuha Medika. 2011

9. Ginting, Laurent. Perbandingan Tingkat Kepuasan Ibu Hamil terhadap Standar Pelayanan Antenatal di Puskesmas Desa Lalang dan Puskesmas Darusalam. http://repository.usu.ac.id/bitstream/12345 6789/19344/7/Cover.pdf. 2010. Diakses tanggal 20 Juli 2016 Pukul 20.21 WIB

10. Winarni. Kepuasan ibu hamil terhadap pelayanan antenatal care (anc) oleh Bidan di Wilayah Kerja Puskesmas Ngoresan. 2014; Gaster Vol XI. 2 Agustus 2014.

11. Santosa PW, Hidayat, Ayat. Riset terapan teori dan aplikasi, mahir menggunakan metode statistika untuk penelitian ilmiah. Jakarta ; PT Globalstant solusi utama; 2014.

12. Aghny Aulia, Surjani, Eko Mardiyaningsih. Gambaran Kepuasan Ibu Hamil terhadap Pelayanan Antenatal Care di Puskesmas Getasan Kabupaten Semarang. Jurnal Keperawatan Maternitas. 2013;1(1): 21-27.

13. Rikhly F. M, Atik Mawarni, Farid Agushybana. Kepuasan Ibu Hamil dan Persepsi Kualitas Pelayanan Antenatal Care di Puskesmas Tanjung Kabupaten Sampang Madura. Media Kesehatan Masyarakat Indonesia. 2012; 11(2)

14. Agatha Maria. Sikap dan Komunikasi Bidan terhadap Tingkat Kepuasan Ibu Hamil pada Pelaksanaan Antenatal Care. Jurnal Vokasi Kesehatan. 2015; 1(5): 136141.

15. Ardhityo, Defrian Risky. Reliabelitas mempengaruhi kepuasan pasien terhadap pelayanan kesehatan di salah satu puskesmas kabupaten ngawi. Jurnal GASTER. 2013; 10(2)

16. Mursyida, Rikhly Faradisy. Kepuasan ibu hamil dan persepsi kualitas pelayanan antenatal care di puskesmas tanjung kabupaten sampang madura. Media Kesehatan Masyarakat Indonesia. 2012;11(2)

17. Wulansari, Neni, Anita. Hubungan antara status ekonomi dan jarak tempuh pada ibu hamil dengan pemilihan penolong persalinan di desa ngendrokilo magelang. Jurnal Kebidanan. 2011;III(1) 